\title{
Daria Targosz
}

Uniwersytet Pedagogiczny im. Komisji Edukacji Narodowej w Krakowie ORCID: 0000-0001-6677-762X

daria.stopa@gmail.com

\section{METAFORYCZNOŚĆ CIAŁA I SPOSOBY OBRAZOWANIA DOŚWIADCZENIA CIELESNEGO}

DOI: $10.52097 /$ acapress. $9788362475810.249-259$

\section{Słowa kluczowe: Streszczenie}

metafora, Szkic podejmuje próbę problematyzacji ciała w oparciu metafora o teorie Mauricéa Merleau-Ponty'ego i somatopoetyki ciała, ciało, Anny Łebkowskiej, a także z uwzględnieniem koncepcielesność, cji choroby jako metafory Susan Sontag. Tekst zawiera somatopoetyka omówienie teorii Merleau-Ponty'ego zawartych m.in. w Fenomenologii percepcji, a opierających się na założeniu podmiotowości ciała i jego niesprowadzalności do poziomu rzeczy. Ponadto szkic omawia przedstawione przez francuskiego filozofa argumenty mówiące o podmiotowości ciała. Natomiast $z$ koncepcji somatopoetyki, która odnosi się do zasad i sposobów uobecnienia się kategorii cielesności, autorka tekstu czerpie narzędzia służące do analizy tekstów za pomocą metafory ciała oraz założenia o potrzebie rozpoznania czy uchwycenia kategorii cielesności, a zarazem o świadomości oporu, który stawia cielesność. Tekst nakreśla także rolę ciała i podejmuje próbę określenia statusu ciała we współczesnej refleksji humanistycznej. Autorka zwraca uwagę na konieczność uwzględnienia spojrzenia na ciało ludzkie, mającego na uwadze jego specyficznie podmiotowy charakter (w przeciwieństwie do przedmiotowego postrzegania ciała). Tekst podejmuje temat sposobów obrazowania doświadczenia cielesnego oraz omawia zagadnienie ciała jako metafory. 


\section{Keywords: Abstract}

metaphor, The sketch attempts to problematize the issue of the body body based on the Maurice Merleau-Ponty's and Anna metaphor, Łebkowska's theories, and also it considering Susan body, Sontag's essay Illness as a metaphor. The text discusses corporeality, Maurice Merleau-Ponty's theories contained, among somato-poetics others, in the Phenomenology of Perception, based on the assumption of the subjectivity of the body and its irreducibility to the level of things and also discusses the arguments about the subjectivity of the body presented by the French philosopher. From the Anna Łebkowska's concept of somato-poetics, which refers to the methods and ways of the showing of corporeality, the author of the text takes research perspective for analyzing texts by the metaphor of the body and assuming, that is needed to recognize the category of corporeality, and also is needed to be aware of the resistance that corporeality puts up. The text also outlines the role of the body and attempts to define the status of the body in contemporary humanistic reflection. The author of the text draws attention that is needed to take the view of the human body, remembering about its specific subjective character (as opposed to the objective perception of the body). The text deals with the ways of depicting body experience and discusses the issue of the body as a metaphor.

Spojrzenie na kwestię cielesności z jednej strony wiązało się jeszcze do niedawna $z$ "zakrywaniem ciała” - tabuizowaniem treści związanych z cielesnością, fizjologią czy seksualnością. $\mathrm{Z}$ drugiej strony w ostatnich latach kultura konsumpcyjna zdaje się „odzierać ciało” z wszelkich zasłon. Media, a zwłaszcza kampanie reklamowe, atakując odbiorców rozmaitymi obrazami cielesności, często nacechowanymi erotycznie, stworzyły kult ciała, które wedle napływających zewsząd przekazów musi być piękne, zdrowie i sprawne. Do takiego sposobu ukazywania przyczynił się także rozwój i upowszechnienie się kina i telewizji, które posługując się właściwą im formą przekazu, mogły przedstawić ciało oraz 
związaną z nim seksualność człowieka wprost, co nie było możliwe na taką skalę w przypadku mediów tradycyjnych. Za sprawą reklam, kampanii promocyjnych, a także rozwoju przemysłu kosmetycznego i wzrostu popularności szeroko rozumianego zdrowego stylu życia ciało zostało również zredukowane do obiektu estetycznego oglądu. Do konsekwencji oddziaływań konsumpcjonizmu i kultury masowej należy zmiana statusu ciała, które nie jest już, jak do tej pory, elementem należącym do obszaru natury, ale czymś, co zostało zawładnięte przez kulturę. Jednym z następstw tych zjawisk jest bardzo mocne uprzedmiotowienie ciała. $Z$ punktu widzenia niniejszej pracy warto jednak dostrzec w ciele coś więcej niż tylko powierzchowny, zewnętrzy element człowieczeństwa czy rzecz, którą można poddawać ocenie estetycznej. Warto cielesność potraktować jako ważny element tożsamości człowieka, a relację ciało-dusza rozpatrywać nie jako dychotomię, ale uwzględniając nierozłączny i spójny charakter tej relacji. Anna Łebkowska zwraca uwagę na wynikającą $z$ antropocentryzmu somatyzację otaczającej rzeczywistości, którą trafnie oddaje Lyotardowska formuła "ciało tworzące świat i przezeń tworzone”. Słowa Jeana -Françoisa Lyotarda wskazują na współistnienie i współoddziaływanie dwóch planów - świata i ciała (Łebkowska, 20II, s. I6).

Zmiany społeczno-kulturowe sprawiły, że cielesność oprócz tego, że jest dziedziną zainteresowania i autorefleksji przeciętnego człowieka, pojawia się również jako przedmiot refleksji akademickiej. Tematyka ciała jest eksplorowana przez badania przyrodnicze, społeczne, a także na gruncie refleksji humanistycznej. Ponadto powstają i upowszechniają się nowe dyscypliny, jak np.: socjologia ciała, psychologia ciała, filozofia ciała.

Mimo znacznej eksploracji problematyki cielesności ludzkiej w ostatnim czasie wniosek, że jest to kategoria rozpoznana i oswojona, jest błędny. Jej potencjał - szczególnie na gruncie literaturoznawstwa - nie został wyczerpany, zwłaszcza że kategoria cielesności w ujęciu ponowoczesnym, podważając relacje wnętrze-zewnętrze, zdaje się translokować nienaruszalne dotąd dualizmy, takie jak: jedność-wspólnota, wyrażalne-niewyrażalne, otwarte-zamknięte, swoje-obce, tożsame-inne, szczególnie jednak zmienia relacje podmiotu i przedmiotu (Łebkowska, 20I2). 
Podważenie estetycznego odbioru ciała, który je uprzedmiotawia, przeciwstawienie się redukcji ciała tylko do jego kulturowego przedstawienia może być otwarciem drogi do refleksji nad somatyczną naturą człowieka, do próby odpowiedzi na pytanie, jakim bytem jest człowiek rozumiany jako jednolita całość psychofizyczna. W perspektywie literackiej obecności ciała kluczowa wydaje się kwestia ustawienia ciała w pozycji znaczącej części tekstu, a nie kolejnej figury obecności.

Niniejsza praca ma na celu przybliżenie i omówienie narzędzi badawczych służących do analizy problematyki cielesności. Zasadniczym założeniem badań przedstawionych w nin. tekście jest uwzględnienie spojrzenia na ciało ludzkie, mającego na uwadze jego specyficznie podmiotowy charakter (w przeciwieństwie do przedmiotowego postrzegania ciała). Autorka podejmuje próbę sproblematyzowania kwestii językowej trudności określenia somatycznej natury człowieka, a także bada relacje łączące ciało i język. U podstaw niniejszego tekstu stoi teza, że doświadczenie cielesne przedstawione $\mathrm{w}$ dziele literackim nie odnosi się wyłącznie do samego ciała, ale niesie ze sobą rozmaite sensy, dotyka esencji istnienia. Ta perspektywa wpłynęła na wybór koncepcji, które w najbardziej inspirujący i istotny dla naszych rozważań sposób stawiają ciało w centralnym punkcie. Są to somatopoetyka w ujęciu Anny Łebkowskiej, koncepcja ciała Mauricéa Merleau -Ponty'ego, a także teoria choroby jako metafory Susan Sontag.

Maurice Merleau-Ponty, jako fenomenolog korzystający z wyników badań kognitywistycznych, dostrzegał sensotwórcze cechy ciała i przedstawiał cielesność jako coś, co pozwala na bezpośrednie przeżywanie świata. Szczególnie ważne wydaje się uwzględnienie takich komponentów koncepcji francuskiego filozofa, jak teoria podmiotu wcielonego, rozumienie ciała jako punktu widzenia świata czy ekspresja cielesności.

Zdaniem Merleau-Ponty’ego niezwykłość cielesności objawia się w tym, że ciało nie zawęża się tylko do tego, co jest oglądane, ale jest też tym, co ogląda. Jest jednocześnie i przedmiotem, i podmiotem. Funkcje te działają wymiennie. Francuski filozof przekonywał, że nie ma możliwości posługiwania się ciałem jak narzędziem, ponieważ $\mathrm{w}$ momencie, w którym pojawia się 
intencja użycia ciała, następuje ruch, który należy do ciała. Byłoby ono zatem narzędziem samego siebie. Jednocześnie ciało jest też granicą człowieka, która oddziela go od tego, czym człowiek jest, a czym nie jest (Murawska, 2008). Warto też, w ślad za Merleau-Pontym, sprzeciwić się mechanistycznym teoriom cielesności, uprzedmiotowianiu ciała jako wystawianego na działalnie bodźców bez uwzględnienia możliwych reakcji psychicznych (Gołębiewska, 2004).

Merleau-Ponty w swojej pracy zatytułowanej Fenomenologia percepcji występuje $z$ postulatem nieredukowania ciała do rzeczy. Dowodów związanych z niesprowadzalnością ciała do poziomu rzeczy filozof upatruje w fakcie stałego spostrzegania ciała (w przeciwieństwie do rzeczy, od których można się odwrócić), a także w możliwości patrzenia na rzeczy $z$ różnych perspektyw. Najbardziej przekonującym argumentem zdaje się kwestia podwójnej doznaniowości (sensation double), polegająca na tym, że ciało jednocześnie dotyka, będąc dotykanym (Merleau-Ponty, I945, za: Drwięga, 2002).

Używanie przez Merleau-Ponty'ego określenia „ciało” ma na celu zaznaczenie cielesnej implikacji procesów poznawczych człowieka, jego zachowań, a także kwestii dotyczących pojmowania własnej egzystencji. Należałoby więc mówić tutaj o podmiocie wcielonym, w którym cielesne stapia się z tym, co związane z umysłem, psychiką czy duszą (Gołębiewska, 2004, s. 25I).

Merleau-Ponty nazywał za Heideggerem egzystencję jako „bycie -w-świecie”; osiągalność świata dana poprzez ciało i jego przeżywanie jest pierwotna wobec ujęcia świata będącego przedmiotem poznania. Ciało, samo będąc podmiotowe, jest warunkiem dojścia do przedmiotu poznania. Oznacza to, że wedle tej teorii poznanie rzeczywistości za pomocą ciała wyprzed za świadome rozumienie tego, czym jest świat i jak go widzimy. Opierając się na tej koncepcji, ze samoświadomością odbierającego i działającego podmiotu należy wiązać samo pojęcie świadomości. Samoświadomość podmiotu miałaby bowiem determinować cielesne i umysłowe warunki rozumienia samego siebie i otaczającej rzeczywistości (Gołębiewska, 2004).

Kolejną ważną inspiracją dla problematyzacji spotkania ciała i słowa (zwłaszcza słowa w postaci metafory) jest perspektywa 
badawcza obecna w somatopoetyce Anny Łebkowskiej. Wyłania się ona ze spojrzenia na ciało jako na interpretujące i interpretowane. Somatopoetyka obejmuje sposoby ukazywania się kategorii cielesności w literaturze oraz zasady, według których to się dzieje. Zasady te uobecniają się w postaci relacji między językiem i ciałem oraz między ciałem a literaturą. Ciało może tutaj funkcjonować także jako generator metafor, i niesie to ze sobą efekt somatyzacji otaczającego świata; ciało pojawia się więc na tej płaszczyźnie nie jako temat, ale w roli kategorii interpretacyjnej (Łebkowska, 2012).

We współczesnej refleksji humanistycznej należy mieć także na uwadze wielość takich terminów związanych z ciałem, jak np. „,soma”, , ,korpus”, , „ciało”, „cielesność”, „body”, „Hlesh”, „, somatyka” czy „korporealizm”. Mnogość tych określeń świadczyć może o potrzebie rozpoznania czy uchwycenia kategorii cielesności, a zarazem o świadomości oporu, który stawia cielesność (Łebkowska, 20I2). W tym ujęciu somatopoetyka to „zasady i sposoby uobecnienia się kategorii cielesności w dyskursach kulturowych i zarazem w literaturze". Niemałe znaczenie mają tutaj uwarunkowania społeczno-kulturowe. W zależności od tego, jak przeformułowywane są metody interpretowania ciała przez dyskursy kulturowe oraz w jaki sposób kategoria cielesności warunkuje pojmowanie świata na danym etapie dziejów, istotnym zmianom podlega także sama somatopoetyka jako kategoria interpretacyjna (Łebkowska, 20I2, s. I03). Łebkowska powiada:

Metafory cielesne zawsze towarzyszą społecznościom czy następującym po sobie formacjom kulturowym, są jednak nie tylko zróżnicowane, nie tylko dotyczą wielu zjawisk (wystarczy przypomnieć głowę państwa, cało założycielskie itd.), ale też wiążą się z panującym światopoglądem, koncepcją czasu i przestrzeni, czy z normami kulturowymi. A zatem to, jak ciało jest pojmowane w danej formacji kulturowej, w jej dyskursach, w myśli abstrakcyjnej, rzutuje na nośność metaforyczną (Łebkowska, 2012, s. I05).

I tak społeczeństwo ukazane poprzez metaforę ciała może być intepretowane jako system organiczny lub mechanizm, natomiast 
z perspektywy dyskursu medycznego może być ujmowane w kontekście zaburzeń, choroby, zwyrodnienia czy epidemii. Ujęcie ciała będącego źródłem metafor jest zatem skorelowane $z$ obrazem rzeczywistości, obrazem już zawczasu danym, omówionym, zdefiniowanym kulturowo (Łebkowska, 2012). Autorka Między teoriami a fikcja literacka wskazuje także na metafory dotknięcia ciała występujące w tekstach kultury. Przywołuje w tym miejscu m.in. takie odsłony dotknięcia ciała jak dotknięcie „surowego mięsa” w esejach Jolanty Brach-Czainy (I992, s. I6I), o ciałach „ulatujących (a więc niedających się pochwycić)" u Elizabeth Grosz, a także o doświadczeniu dotyku u Ewy Rewers (Łebkowska, 2012).

Łebkowska podkreśla, że niezależnie od tego, jakiego tematu dotyczy metafora ciała, „ciało niekoniecznie daje się sprowadzić do naturalnego źródła metafor", bowiem metaforyka ta jest silnie sprzężona $z$ aktualną kulturową koncepcją ciała, a więc zależy od tego, czy ciało jest utożsamiane ze sprawnym organizmem, czy traktowane jest może ,jako powłoka bądź pojemnik dla wnętrza duchowego, jako posiadany przedmiot, czy (...) jako ustawiczne przekraczanie wnętrza i zewnętrza, jako wciąż nowe konfiguracje znaczeń itd." (Łebkowska, 20I2, s. I06). Zatem, jak pisze badaczka, metafora społeczeństwa zależy od koncepcji ciała aktualnie panującej w danej formacji kulturowej (Łebkowska, 20I2). W związku z powyższym wskazuje się na potrzebę podważenia istniejących, zadomowionych już konstruktów, automatyzmów (zdarza się, że zadomowienie metafory jest tak mocne, że $z$ czasem staje się ona katachrezą). Potrzebę wytworzenia nowych metafor dostrzec można przede wszystkim w dyskursie feministycznym zmierzającym do zakwestionowania metafor skonstruowanych zgodnie $z$ porządkiem patriarchalnym (Łebkowska, 20I2).

Co szczególnie istotne dla autorki nin. tekstu, Somatopoetyka sygnalizuje też - pojawiający się równocześnie w systematycznie zwiększającym się zainteresowaniem ciałem - paradoksalny problem jego desomatyzacji. Według Łebkowskiej (2012) współcześnie można mówić o:

ustawicznym wymykaniu się tego co cielesne. W efekcie migotliwej, metaforycznej i jednocześnie zawłaszczonej przez kulturę obecno- 
ści ciała tworzącego świat i przezeń kształtowanego - ulega ono odcieleśnieniu i - by tak rzec - zanikowi. Innymi słowy zostaje zdesomatyzowane: jako nośnik oznacza w istocie co innego, jako temat - okazuje się też jedynie zapisem kultury (s. II5-II6).

Powyżej wskazane zjawisko jest konsekwencją niezupełnego wpisania ciała w kody kultury, przez co podmiot nie może uchwycić swojej cielesności (Łebkowska, 20I2). Kwestię niepełnego wpisania ciała w kody kultury Anna Łebkowska obrazuje cytatem z Lyotarda: „Ciało, które jednoczy się ze światem, bo należy do świata, które tworzy świat i jest przezeń tworzone: a zarazem ciało, które wycofuje się ze świata w mrok tego, co utraciło, po to by się w nim narodzić" (Lyotard, I998, s. I22). Paradoksalnie jednak w tym, co nieuchwytne, dostrzec można nie tylko coś niebezpiecznego, ale także źródło twórczości. Bowiem to, co niepojmowalne, objawiać się może w języku w postaci „pęknięć, szczelin, rys, uskoków”; to zaburzenie, ta fragmentaryczność skutkować może oporem wobec tego, co oficjalne, podważeniem dyskursów kulturowych i w ten sposób okazać się może właśnie źródłem twórczości (Łebkowska, 20I2).

Warto również zwrócić uwagę na granice cielesności, pamiętając o szczególnych zależnościach między tym, co cielesne i bezcielesne, żywe i martwe, ludzkie i nieludzkie (naturalne i sztuczne). Mówiąc o tych opozycjach, nie sposób pominąć relacji ciało przezroczyste i ciało nieprzezroczyste. Pierwsze to takie, które jest oczywiste i przez to niezauważalne, niepodlegające opisowi, niezasługujące na przedstawienie. Ciałem nieprzezroczystym byłoby natomiast ciało, które w jakiś sposób traci swoją oczywistość, szczególnie w związku z jakimś rodzajem inności, bycia poza normą (mieszczą się tutaj m.in. takie aspekty związane $z$ cielesnością jak‡ choroba, cierpienie ciała, starzenie się, ale te $\dot{z}$ dojrzewanie czy napiętnowanie) (Łebkowska, 20I2). Zastanawiając się nad granicami związanymi z cielesnością, należałoby także poruszyć kwestię relacji pomiędzy wnętrzem a zewnętrzem. Jean -Luc Nancy stoi na stanowisku, że ciało, nie mając miejsca ani $\mathrm{w}$ dyskursie, ani w materii, umieszczone jest właśnie na granicy, w miejscu spotkania tego, co ciągłe, $z$ tym, co obce, że ciało to pewien „rozłam w ciągłości materii” (Nancy, 2002, s. I8). 
Jeśli chodzi o ciało jako metaforę choroby, nie sposób pominąć teorii Susan Sontag, która w swoich esejach Choroba jako metafora oraz AIDS i jego metafory na przykładach tekstów literackich oraz innych tekstów kultury opisuje metaforykę gruźlicy, raka i AIDS. Sontag pisze o mitologizacji gruźlicy jako metafory miłości, tłumionej „namiętności, która trawi”. Atak tuberkulozy miałby wiązać się z objawem jakiegoś rodzaju namiętnego uczucia. Sontag powiada, że gruźlica:

Dla pnących się w górę snobów i parweniuszy tego okresu [osiemnastego wieku - D.T.] była świadectwem ogłady, subtelności i wrażliwości (...) Gruźlicę rozumiano jako pewien typ powierzchowności, ta zaś stała się przedmiotem ambicji wieku dziewiętnastego. Jedzenie $z$ apetytem przyjmowane było jako nietakt. Chory wygląd został uznany za synonim urody (...) Ukształtowany pod wpływem gruźlicy ideał urody stał się nowym standardem arystokratycznego wyglądu - i to akurat $\mathrm{w}$ chwili, kiedy arystokracja przestaje oznaczać siłę, a zaczyna być jedynie sprawą aparycji (...) W istocie romantyzacja gruźlicy to pierwszy powszechny przykład typowo nowoczesnej tendencji, jaką jest utożsamianie wyglądu z osobowością. Gruźliczy wygląd musiał zostać uznany za atrakcyjny, skoro dostrzegano już wcześniej w nim znamię dostojeństwa i szlachetnego urodzenia (Sontag, 1984, s. 216-217).

Sontag przywołuje mitologizacje chorób, według których rak, podobnie jak gruźlica, pojmowany był jako choroba namiętności. $Z$ tą różnicą, że gruźlica miała powstawać $z$ nadmiaru namiętności u ludzi zbyt zmysłowych, a rak miałby być powodowany niedostatkiem namiętności, atakując ludzi tłumionych wewnętrznie, pozbawionych umiejętności uzewnętrzniania gniewu; zgodnie $z$ mitologią nowotworu "namiętnością, która dziś sprowadzać ma raka, jeśli nie znajdzie gdzieś ujścia, jest złość" (Sontag, I984, s. 214). Badaczka powiada także, że aktualnie gruźlica czy nowotwór w przeciwieństwie do innych chorób, niosą ze sobą „konkretny ładunek retoryczny”, pojawiając się „tam, gdzie idzie o sformułowanie nowych, polemicznych definicji zdrowia jednostki oraz wyrażenie niezadowolenia ze społeczeństwa jako takiego" 
(Sontag, 1984, 230). Sontag porównuje współczesne metafory tych chorób do tych z czasów elżbietańskich, których nie odczytywano przez pryzmat społeczeństwa, mogły ukazywać ,jakieś powszechne odchylenie od normy lub społeczną klęskę", jednak musiałyby one mieć istotny wpływ na jednostkę (Sontag, 1984, s. 230).

Autorka Stylów radykalnej woli dowodzi, że metaforę choroby aktualnie wykorzystuje się nie w celu zarzucenia społeczeństwu braku równowagi, ale by wskazać na represyjny charakter społeczeństwa. Badaczka podaje przykład, opartej na Damie kameliowej Aleksandra Dumasa, opery Giuseppe Verdiego Traviata. Jej bohaterka, zabrana przez zakochanego w niej mężczyznę z pełnego występku Paryża na wieś, zdrowieje, jednak odrzucenie przez nią uczucia i powrót do miasta sprawia, że gruźlica znów atakuje i kobieta umiera (Sontag, 1984).

$\mathrm{Na}$ literaturę warto spojrzeć przez pryzmat powyższych koncepcji dotyczących cielesności. Otwierają one nowe kierunki analizy, w których ciało odgrywa kluczową rolę jako temat, ale i jako narzędzie badawcze. Ciałem można posługiwać się jako metaforą otaczającego świata. Poprzez metaforę ciała możemy wyrazić np. kondycję społeczeństwa czy zagubienie się w nim jednostki. Ukazane w tekstach literackich (a także innych tekstach kultury) metafory ciała i sposoby obrazowania doświadczenia cielesnego, interpretując rzeczywistość przez pryzmat cielesności, odnoszą się do otaczającego świata, przypisują mu rozmaite sensy, dotykają istoty ludzkiego istnienia.

\section{Bibliografia}

Brach-Czaina, J. (1992). Szczeliny istnienia. Warszawa: PIW. Lyotard, J.-F. (1998). Postmodernizm dla dzieci. Warszawa: Aletheia. Łebkowska, A. (2011). Jak ucieleśnić ciało: o jednym z dylematów somatopoetyki. Teksty Drugie, 4, s. II-27.

Łebkowska, A. (2012). Somatopoetyka. W: R. Nycz, T. Walas (red.). Kulturowa teoria literatury 2. Poetyki, problematyki, interpretacje (s. IoI-I36). Kraków: Universitas. 
Murawska, M. (2008). Tajemnica żywej cielesności. Fenomenologia ciała w ujęciu Mauricéa Merleau-Ponty'ego i Michela Henry'ego. Sztuka i Filozofia, 33, s. I27-I44.

Gołębiewska, M. (2004). Sensotwórcza rola ciała w samopoznaniu według Maurice’a Merleau-Ponty'ego. Teksty Drugie, 1-2, s. 237-25I.

Drwięga, M. (2002). Ciało człowieka. Studium $z$ antropologii filozoficznej. Kraków: Księgarnia Akademicka.

Nancy, J.-L. (2002). Corpus. Gdańsk: Słowo/obraz terytoria.

Sontag, S. (1984). Choroba jako metafora. Fragmenty. W. M. Janion, S. Rosiek (red.). Osoby (s. 212-240). Gdańsk: Wydawnictwo Morskie. 